\title{
PENGARUH PARTISIPASI ANGGARAN, KETEPATAN ANGGARAN TERHADAP SENJANGAN ANGGARAN DENGAN KOMITMEN ORGANISASI SEBAGAI VARIABEL MODERASI (STUDI PADA PEMERINTAH KABUPATEN JAYAPURA)
}

\author{
ABSTRACT \\ Meise Kalembang ${ }^{1}$ \\ kalembangmeise@gmail.com \\ Paulus K. Allo Layuk ${ }^{2}$ \\ paskal1967@yahoo.com \\ Syaikhul Falah ${ }^{3}$ \\ sehufalah@gmail.com
}

The purpose of this research is to understand the influence of the participation and the budget acuracy against budget gap with a current commitment of organization as moderation variables. This kind of research is quantitative research by the use of the primary data. The research population is civil servants of SKPD in Jayapura regency. The amount of sample was 105. Method used in the study was moderated regression analysis.

The results of this study found that the budgeting participation has a positive and significant impact on budget gap, while the budget accuracy can not have positive and significant impact on budget gap. Organization commitment as moderate variable cannot moderating budgeting participation and the budget accuracy to budget gap in Jayapura regency.

Keywords: Budget participation, budget accuracy, budget gap, organization commitment.

\section{PENDAHULUAN}

Ukuran finansial secara umum memberikan informasi tentang estimasi kinerja keuangan dalam periode waktu tertentu.Anggaran ini dimaksudkan agar pemerintah mengetahui sebatas mana kemampuan yang dimiliki pemerintah dalam melaksanakan tugasnya agar selaras dengan tujuan pemerintah dan kebutuhan masyarakat.

Dengan demikian proses penyusunan dan penetapan anggaran

\footnotetext{
${ }^{1}$ Alumni Mahasiswa Magister Keuangan Daerah Universitas Cenderawasih

2 Staf Dosen Jurusan IImu Akuntansi Fakultas Ekonomi \& Bisnis Universitas Cenderawasih

${ }^{3}$ Staf Dosen Jurusan Ilmu Akuntansi Fakultas Ekonomi \& Bisnis Universitas Cenderawasih
} 
dalam pemerintahan menerapkan anggaran partisipatif. Menurut Use the "Insert Citation" button to add citations to this document.

Partisipasi penganggaran adalah proses yang menggambarkan individu-individu terlibat dalam penyusunan anggaran dan mempunyai pengaruh terhadap target anggaran dan perlunya penghargaan atas pencapaian target anggaran tersebut. (Falikhatun 2007).

Fenomena yang terjadi di Kabupaten Jayapura dalam upaya meningkatkan senjangan anggaran yang terjadi Pemerintah Kabupaten Jayapura, Pemerintah Provinsi Papua bersama-sama Pemerintah Kabupaten Jayapura melakukan workshop Replikasi Perencanaan Keuangan Daerah berbasis Elektronik (E-Planing).

Dengan adanya workshop Replikasi Perencanaan Keuangan Daerah berbasis Elektronik (E-Planing) Pemerintah Kabupaten Jayapura mampu melaksanakan Perencanaan yang Efektif, Transparansi, dan mampu meminimalkan korupsi yang terjadi.

Faktor yang menyebabkan mengapa pemerintah Kabupaten Jayapura belum mampu mengatasi senjangan anggaran yang terjadi pada Pemerintah Kabupaten Jayapura salah satunya adalah senjangan anggaran. Senjangan anggaran adalah partisipasi penyusunan anggaran.

Di mana menurut (Mulyadi 2001) partisipasi anggaran berarti keikutsertaan operating managers dalam memutuskan bersama dengan komite anggaran mengenai rangkaian kegiatan di masa yang akan datang yang akan ditempuh oleh operating managers tersebut dalam pencapaian sasaran anggaran.

Faktor selanjutnya yang mempengaruhi senjangan anggaran adalah komitmen organisasi, Menurut (Latuheru 2005) komitmen organisasi bisa tumbuh disebabkan individu memiliki ikatan emosional terhadap organisasi yang meliputi dukungan moral dan menerima nilai yang ada di dalam organisasi serta tekad dalam diri untuk berbuat sesuatu agar dapat menunjang keberhasilan organisasi sesuai dengan tujuan dan lebih 
mengutamakan kepentingan organisasi dibandingkan kepentingannya sendiri.

Faktor yang terakhir yang mempengaruhi kesenjangan anggaran adalah ketepatan anggaran, Ketepatan sasaran anggaran dalam sistem pemerintahan daerah merupakan hal yang sangat diperlukan untuk mengetahui kinerja yang terjadi di lapangan apakah tepat pada sasaran pembangunan dan perkembangan masyarakat.

Aparatur pemerintah daerah memiliki kejelasan untuk mengelola keuangan dengan tepat sehingga penyusunan anggaran pada periode selanjutnya dapat tercapai dengan baik pada instansi pemerintah. Ketepatan sasaran anggaran pada pemerintah daerah akan memberikan implikasi terhadap kinerja aparatur daerah yang lebih baik, maka hasil akhir dari kinerja sendiri merupakan hasil akhir (output) organisasi yang sesuai dengan tujuan organisasi (Suwandi, A. P. 2013).

Sedangkan pendapat para pakar diantaranya seperti Otley (1980) memberikan pendapat tentang Teori Kontijensi dapat digunakan untuk menganalisis desain dan system akuntansi manajemen dalam memberikan informasi kepada perusahaan dalam memilih beberapa jalan untuk mencapai tujuan organisasi.

Dalam partisipasi penyusunan anggaran, penggunaan teori kontijensi telah lama menjadi perhatian para peneliti. Sementara itu, apabila dilihat dari hasil penelitian yang melihat pengaruh partisipasi anggaran terhadap kinerja pemerintah daerah mempunyai factor kontijensi.

Para peneliti di bidang akuntansi menggunakan teori kontijensi saat menghubungkan pengaruh partisipasi anggaran terhadap kinerja aparat pemerintah daerah. Faktor yang dimaksud dalam kontijensi adalah faktor kepuasan kerja dan komitmen organisasi sebagai variable moderating yang dapat memperkuat atau memperlemah partisipasi anggaran dan kinerja pemerintah daerah.

Selanjutnya expectancy theory yang menjelaskan bahwa motivasi individu dapat ditentukan oleh expentancies dan valence. Expectancies 
merupakan satu keyakinan tentang perilaku tertentu (misalnya bekerja lebih giat) akan menimbulkan hasil yang maksimal. Valences berarti nilai yang diberikan individu atas outcome (hasil) atau rewards yang akan dia terima.

Senjangan Anggaran. (Govindarajan 2007) mendefinisikan senjangan anggaran adalah "The difference between the budget amount and the best estimate is called", yang berarti perbedaan jumlah anggaran yang diajukan oleh bawahan dengan jumlah estimasi terbaik dari organisasi.

Selanjutnya pendapat (Hansen, D. R., Mowen, M. M., \& Guan, L. 2007) yang menyatakan bahwa "Problem with participate budgeting is the opportunity for managers to build slack into budget". Selanjutnya (Hansen et al. 2007) menyatakan:

"Budgetary slack (or padding the budget) exist when a manager deliberately underestimates revenues or overestimates cost. Either approach increases the likelihood that the manager will achieve the budget and consequently reduces the risk that the manager faces. Padding the budget also unnecessarily tiep up resources that might be used more productively else where".

Senjangan anggaran (budget slack) adalah perbedaan antara jumlah anggaran dan jumlah estimasi terbaik (Anthony, R. N., \& Govindarajan. 2007). Senjangan anggaran adalah perbedaan antara anggaran yang dinyatakan dan estimasi anggaran terbaik yang secara jujur dapat diprediksi serta dibuat oleh penyusun anggaran dalam penganggaran.

Menurut (Dunk 1993) manajer lebih cenderung menyusun anggaran yang lebih mudah untuk dicapai. Prilaku manajer melakukan senjangan anggaran dipengaruhi oleh kebijakan direktur yang menilai kinerja manajer berdasarkan pencapaian sasaran anggaran. Senjangan anggaran biasanya dilakukan dengan meninggikan biaya atau menurunkan pendapatan dari yang seharusnya, supaya anggaran mudah dicapai.

Dalam kaitan ini, Chilf, M., \& Lewin, A. A. 1970 memberikan pendapat bahwa manajer dapat menciptakan senjangan anggaran melalui 
pengecilkan pendapatan dan memperbesar biaya. Senjangan anggaran diciptakan oleh manajer yang dapat mengatur dan menyembunyikan beberapa informasi pribadi dari atasan mereka dan sengaja menggambarkan informasi yang hanya dapat menguntungkan diri mereka sendiri melalui pengenalan senjangan (Hasanah, C. U., \& Suartana, I. W. 2014).

Partisipasi anggaran adalah proses yang menggambarkan keterlibatan individu-individu dalam penyusunan anggaran dan mempunyai pengaruh terhadap target anggaran dan perlunya penghargaan atas pencapaian target anggaran tersebut (Amelia, F., Yusralaini, \& Azhar, A. 2014). Adanya partisipasi dalam penyusunan anggaran sering dikatakan efektif, efisien, dan informasi yang dihasilkan lebih akurat.

Keterlibatan partisipasi berbagai pihak dalam membuat keputusan dapat terjadi dalam penyusunan anggaran. Partisipasi dalam penyusunan anggaran diartikan oleh (Sugiwardani, R. 2012) sebagai "keikutsertaan operating managers dalam memutuskan bersama dengan komite anggaran mengenai rangkaian kegiatan di masa yang akan datang yang akan ditempuh oleh operating managers tersebut dalam pencapaian sasaran anggaran".

Partisipasi juga menghasilkan peluang yang lebih besar dari bawahan untuk menciptakan senjangan anggaran hal tersebut mengacu pada pendapat bahwa partisipasi anggaran akan meningkatkan senjangan anggaran Dunk, 1993; (Mark Young, 1985) dalam (Ikhsan \& Ane 2007). Diperkuat oleh pendapat Antie dan Eppen (1985) dalam (Ikhsan, A., \& Ane, L. 2007) bahwa "partisipasi akan menciptakan senjangan anggaran".

Argumen yang diajukan adalah bahwa semakin tinggi partisipasi yang diberikan kepada bawahan, bawahan cenderung berusaha agar anggaran yang mereka susun mudah dicapai, salah satu cara yang ditempuh adalah dengan melonggarkan anggaran atau menciptakan senjangan. 
Berdasarkan uraian konseptual teoritis dan hasil kajian empiris yang telah dikemukakan, maka hipotesis yang dikemukakan dalam penelitian ini adalah sebagai berikut:

\section{H1: Terdapat pengaruh positif partisipasi anggaran terhadap senjangan anggaran}

Ketepatan anggaran dalam sistem pemerintahan daerah merupakan hal yang sangat diperlukan untuk mengetahui kinerja yang terjadi di lapangan apakah tepat pada sasaran pembangunan dan perkembangan masyarakat.

Aparatur pemerintah daerah memiliki kejelasan untuk mengelola keuangan dengan tepat sehingga penyusunan anggaran pada periode selanjutnya dapat tercapai dengan baik pada instansi pemerintah.

Ketepatan sasaran anggaran pada pemerintah daerah akan memberikan implikasi terhadap kinerja aparatur daerah yang lebih baik, maka hasil akhir dari kinerja sendiri merupakan hasil akhir (output) organisasi yang sesuai dengan tujuan organisasi (Suwandi, 2013).

Penelitian oleh (Dewi, M. A. P. \& Supadmi, N. L. 2015) menemukan bahwa ketepatan sasaran anggaran berpengaruh positif terhadap akuntabilitas kinerja SKPD. Berdasarkan uraian konseptual teoritis dan hasil kajian empiris yang telah dikemukakan, maka hipotesis yang dikemukakan dalam penelitian ini adalah sebagai berikut:

\section{H2: Terdapat pengaruh positif partisipasi anggaran terhadap senjangan anggaran}

Komitmen organisasi secara umum akan menciptakan loyalitas karyawan melaluai beberapa aspek meliputi penerimaan saran-saran, nilainilai organisasi, kesediaan atau kemauan untuk menjadi bagian dari organisasi serta bisa bertahan selama mungkin . (Sugiwardai R. 2012) menjelaskan komitmen organisasi merupakan salah satu factor penting dalam pencapaian organisasi. 
Berdasarkan uraian konseptual teoritis dan hasil kajian empiris yang telah dikemukakan, maka hipotesis yang dikemukakan dalam penelitian ini adalah sebagai berikut:

\section{H3: Komitmen organisasi dapat memoderasi pengaruh partisipasi anggaran terhadap senjangan anggaran.}

Ketepatan sasaran anggaran pada pemerintah daerah akan memberikan implikasi terhadap kinerja aparatur daerah yang lebih baik, maka hasil akhir dari kinerja sendiri merupakan hasil akhir (output) organisasi yang sesuai dengan tujuan organisasi (Suwandi 2013).

Berdasarkan uraian konseptual teoritis dan hasil kajian empiris yang telah dikemukakan, maka hipotesis yang dikemukakan dalam penelitian ini adalah sebagai berikut:

\section{H4: Komitmen organisasi dapat memoderasi pengaruh ketepatan anggaran terhadap senjangan anggaran.}

Model konseptual penelitian di bawah ini dirancang berdasarkan model kajian-kajian terdahulu terlihat pada gambar di bawah ini:

\section{Gambar 1 Kerangka Konseptual}

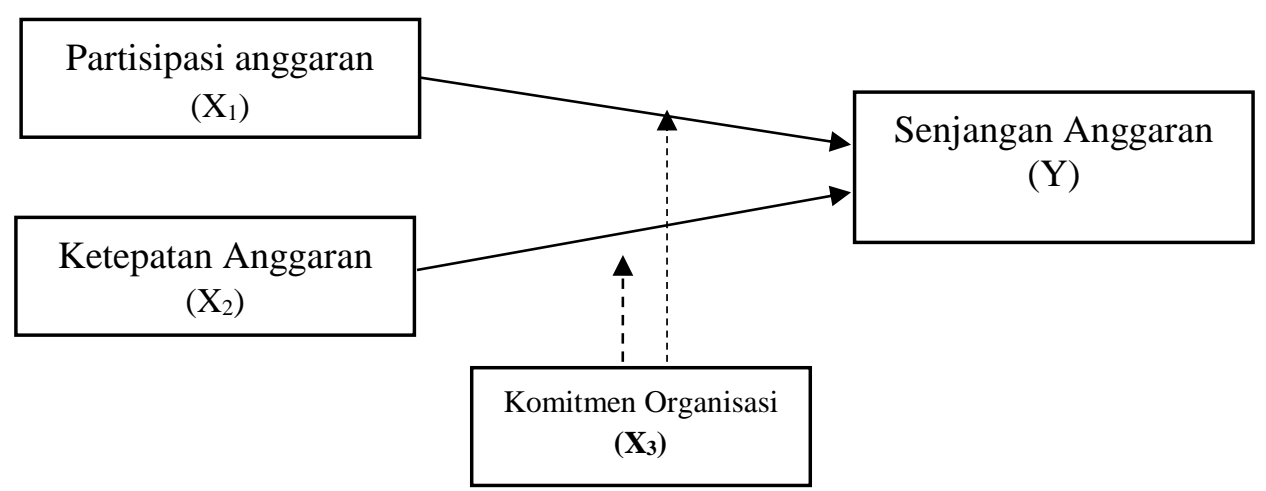

\section{METODE PENELITIAN}

\section{Lokasi, Populasi dan Sampel Penelitian}

Penelitian ini dilakukan pada Satuan Kerja Pemerintah Daerah Kabupaten Jayapura di Sentani. Lokasi penelitian berada pada kantor bupati yang berada di jalan. Gunung Merah Kabupaten Jayapura. 
Populasi dalam penelitian ini adalah pegawai bagian akuntansi atau penatausahaan keuangan di OPD yang meliputi Dinas, Badan, dan Kantor di Pemerintah Kabupaten Jayapura. Adapun jumlah Dinas, Badan, dan Kantor di Pemerintah Kabupaten Jayapura adalah sebanyak 35 Organisasi Perangkat Daerah (OPD).

Sampel adalah subyek dari populasi, yang terdiri dari beberapa anggota populasi yaitu: pegawai bagian akuntansi atau penatausahaan keuangan dan bagian yang menangani sistem pengendalian intern OPD.

Teknik penarikan sampel yang digunakan dalam penelitian ini menggunakan metode probability sampling. sementara teknik penarikan sampel yang digunakan adalah teknik purposive sampling, dengan kriteria penarikan sampel sebagai berikut: (1) Responden adalah pegawai negeri sipil (PNS); (2) Responden yang menduduki jabatan Kepala bagian keuangan, Kepala bagian akuntansi dan Bendahara.

\section{Teknik Analisis Data}

Untuk menjawab permasalahan-permasalahan penelitian disesuaikan dengan model hipotesis, di mana untuk menguji hipotesis penelitian ini menggunakan Analisis regresi moderasi (Moderated Regression Analysis). Model Analisis regresi moderasi (Moderated Regression Analysis) adalah untuk mengetahui pengaruh antara variabel independent terhadap variabel dependent dan disertakan variabel moderating. Variabel moderating adalah variabel yang memperkuat atau memperlemah hubungan variabel independent terhadap variabel dependent (Ghozali, I 2005).

Bentuk rumusan persamaan matematis dari Analisis regresi moderasi (Moderated Regression Analysis) yang digunakan adalah sebagai berikut :

Model Persamaan pengujian Hipotesis sebagai berikut:

$$
S A=a+\beta 1 P A+\beta 2 K A+\beta 3 K O+\beta 4 b K O+\beta 5 P A^{*} K O+\beta 6 K A^{*} K O+e
$$

Keterangan : 
SA $=$ Senjangan Anggaran

PA $\quad=$ Partisipasi Anggaran

$\mathrm{KA} \quad=$ Ketepatan Anggaran

$\mathrm{KO}=$ Komitmen Organisasi

$\mathrm{PA}^{*} \mathrm{KO}=$ Interaksi antara partisipasi anggaran dengan Komitmen Organisasi

$\mathrm{KA}^{*} \mathrm{KO}=$ Interaksi antara ketepatan anggaran dengan Komitmen Organisasi

\section{HASIL}

\section{Karakteristik Responden}

Pada bagian ini akan dijelaskan tentang karakteristik responden (Pegawai Badan Kepegawaian, Pendidikan dan Pelatihan) sebanyak 97 responden yang dibagi berdasarkan usia, jenis kelamin dan pendidikan, seperti yang terlihat pada Tabel 1 di bawah ini.

Tabel 1 Karakteristik Responden

\begin{tabular}{|l|l|c|c|}
\hline Kategori & Sub Katagori & Frekuensi & $\begin{array}{c}\text { Persentase } \\
(\%)\end{array}$ \\
\hline \multirow{4}{*}{ Usia } & $30-35$ Tahun & 5 & 5,15 \\
\cline { 2 - 4 } & $35-40$ Tahun & 23 & 23,71 \\
\cline { 2 - 4 } & 45 - 50 Tahun & 37 & 38,14 \\
\cline { 2 - 4 } & $>50$ Tahun & 32 & 32,99 \\
\hline Jumlah & & $\mathbf{9 7}$ & $\mathbf{1 0 0}$ \\
\hline \multirow{2}{*}{ Jenis Kelamin } & Laki-laki & 56 & 57,73 \\
\cline { 2 - 4 } & Perempuan & 41 & 42,27 \\
\hline \multirow{4}{*}{ Jumlah } & & $\mathbf{9 7}$ & $\mathbf{1 0 0}$ \\
\hline \multirow{3}{*}{ Jendidikan } & SLTA/Sederajat & 23 & 23,71 \\
\cline { 2 - 4 } & Diploma Tiga & 7 & 7,22 \\
\cline { 2 - 4 } & Sarjana Satu (S1) & 55 & 56,70 \\
\cline { 2 - 4 } & Sarjana Dua (S2) & 12 & 12,37 \\
\hline & & $\mathbf{9 7}$ & $\mathbf{1 0 0}$ \\
\hline
\end{tabular}

Deskripsi karakteristik responden di atas menunjukkan bahwa:

1. mayoritas responden penelitian ini berusia 45-50 tahun (37 responden atau $38.14 \%$ dari total responden)

2. didominasi oleh responden laki-laki yaitu sebesar 56 orang atau $57.73 \%$, dan 
3. relatif berpendidikan tinggi dengan didominasi oleh responden strata satu (S1) sebanyak 55 orang atau $56.70 \%$.

Data di atas secara tidak langsung menunjukkan bahwa secara ratarata responden telah berpengalaman dalam menjalankan apa yang menjadi tugas pokok dan fungsi mereka.

\section{Hasil Uji Instrumen}

Hasil uji instrumen penelitian ini dapat diuraikan sebagai berikut:

Tabel 2 Uji Validitas

\begin{tabular}{|c|c|c|c|c|}
\hline Variabel & Item & $\begin{array}{c}\text { Koefisien } \\
\text { Korelasi }\end{array}$ & Sig & Ket. \\
\hline \multirow{6}{*}{$\begin{array}{c}\text { Partisipasi } \\
\text { Penyusunan } \\
\text { Anggaran }\end{array}$} & $\mathrm{X}_{1.1}$ & 0,912 & 0.000 & Valid \\
\hline & $\mathrm{X}_{1.2}$ & 0,886 & 0.000 & Valid \\
\hline & $\mathrm{X}_{1.3}$ & 0,857 & 0.000 & Valid \\
\hline & $\mathrm{X}_{1.4}$ & 0,862 & 0.000 & Valid \\
\hline & $\mathrm{X}_{1.5}$ & 0,790 & 0.000 & Valid \\
\hline & $\mathrm{X}_{1.6}$ & 0,751 & 0.000 & Valid \\
\hline \multirow{4}{*}{ Ketetapan Anggaran } & $\mathrm{X}_{2.1}$ & 0,779 & 0.000 & Valid \\
\hline & $\mathrm{X}_{2.2}$ & 0,812 & 0.000 & Valid \\
\hline & $\mathrm{X}_{2.3}$ & 0,783 & 0.000 & Valid \\
\hline & $X_{2.4}$ & 0,761 & 0.000 & Valid \\
\hline \multirow{8}{*}{$\begin{array}{l}\text { Komitmen } \\
\text { Organisasi }\end{array}$} & $X_{3.1}$ & 0,740 & 0.000 & Valid \\
\hline & $X_{3.2}$ & 0,735 & 0.000 & Valid \\
\hline & $\mathrm{X}_{3.3}$ & 0,745 & 0.000 & Valid \\
\hline & $X_{3.4}$ & 0,807 & 0.000 & Valid \\
\hline & $\mathrm{X}_{3.5}$ & 0,806 & 0.000 & Valid \\
\hline & $X_{3.6}$ & 0,813 & 0.000 & Valid \\
\hline & $X_{3.7}$ & 0,812 & 0.000 & Valid \\
\hline & $\mathrm{X}_{3.8}$ & 0,722 & 0.000 & Valid \\
\hline \multirow{6}{*}{$\begin{array}{c}\text { Senjangan } \\
\text { Anggaran }\end{array}$} & $Y_{1.2}$ & 0,737 & 0.000 & Valid \\
\hline & $Y_{1.3}$ & 0,716 & 0.000 & Valid \\
\hline & $Y_{1.4}$ & 0,655 & 0.000 & Valid \\
\hline & $Y_{1.5}$ & 0,726 & 0.000 & Valid \\
\hline & $Y_{1.6}$ & 0,667 & 0.000 & Valid \\
\hline & $Y_{1.2}$ & 0,688 & 0.000 & Valid \\
\hline
\end{tabular}

Hasil pengujian validitas di atas dapat disimpulkan valid, karena tingkat probabilitas (sig) atau tingkat signifikansi hasil pengujian lebih kecil dari 0,05 . 
Tabel 3 Uji Reliabilitas

\begin{tabular}{|c|c|c|}
\hline Variabel & $\begin{array}{c}\text { Koefisien } \\
\text { Alpha }\end{array}$ & Keterangan \\
\hline Partisipasi Penyusunan Anggaran & 0,919 & Reliabel \\
\hline Ketepatan Anggaran & 0,791 & Reliabel \\
\hline Komitmen Organisasi & 0,904 & reliabel \\
\hline Senjangan Anggaran & 0,790 & reliablel \\
\hline
\end{tabular}

Hasil uji di atas menunjukkan bahwa koefisien alpha cronbach di atas 0,6 sehingga dapat disimpulkan bahwa data kedua variabel terteliti adalah reliable (dapat diandalkan).

\section{Uji Asumsi Klasik}

\section{Uji Normalitas}

Pengujian normal tidaknya distribusi data penelitian ini dilakukan dengan melihat penyebaran data pada normal probability plot. Tampilan hasil pengujian normal probability plot data penelitian terlihat di bawah ini.

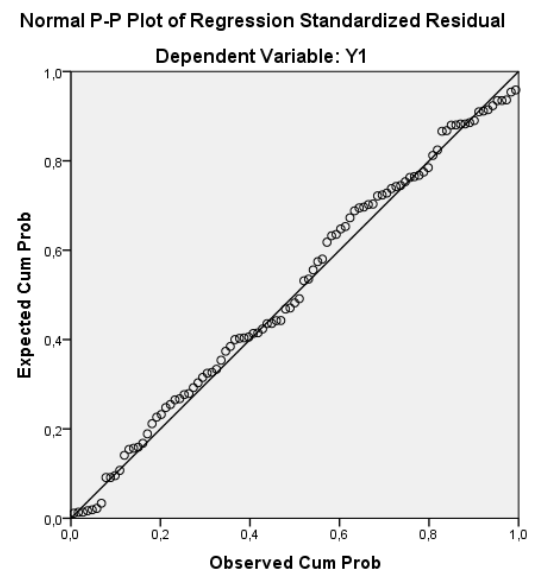

\section{Gambar 2 Hasil Pengujian Normalitas}

Berdasarkan normal probability plot di atas, maka data penelitian ini dapat dikatakan telah memenuhi kaidah normalitas karena terlihat bahwa 
data menyebar mengikuti garis diagonal, penyebarannya secara acak dan tidak membentuk pola tertentu.

\section{Uji Multikolinearitas}

Berikut ini adalah hasil Pengujian multikolinearitas seperti yang terlihat di bawah ini;

\section{Tabel 4 Pengujian Multikolinieritas}

\begin{tabular}{|l|c|c|}
\hline \multirow{2}{*}{ Model } & \multicolumn{2}{|c|}{ Collinearity Statistics } \\
\cline { 2 - 3 } & Tolerance & VIF \\
\hline Partisipasi Penyusunan Anggaran & 0.254 & 3,934 \\
\hline Ketepatan Anggaran & 0.254 & 3,934 \\
\hline
\end{tabular}

Data di atas menunjukkan bahwa nilai tolerance mendekati 1 dan nilai VIF berada di bawah 10 yang berarti tidak terjadi multikolinearitas antar variabel independen dalam penelitian ini.

\section{Uji Heteroskedastisitas}

Pengujian heteroskedastisitas dalam penelitian ini dilakukan dengan melihat gambar charts scatterplot. Berikut ini adalah hasil pengujian heteroskedastisitas yang terlihat pada gambar charts scatterplot dibawah ini.

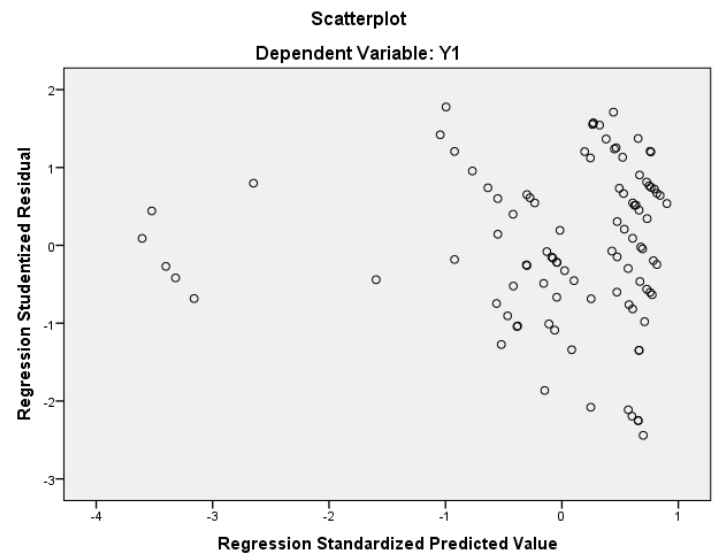

Gambar 3 Hasil Pengujian Heterokedastisitas 
Gambar di atas menunjukkan bahwa data penelitian bebas heterokedastisitas karena titik-titik data menyebar di atas dan di bawah angka 0 pada sumbu $Y$.

\section{Pembuktian Hipotesis}

Berikut ini merupakan hasil pengujian hipotesis 1-4 ditampilkan pada tabel berikut ini:

Tabel 5 Pengujian Hipotesis 1-4

\begin{tabular}{|l|r|r|r|}
\hline Variabel independen & \multicolumn{1}{|c|}{ Beta } & \multicolumn{1}{l|}{ t hitung } & \multicolumn{1}{l|}{ Sig } \\
\hline Partisipasi Penyusunan Anggaran & 0,669 & 5,816 & 0,000 \\
\hline Ketepatan Anggaran & 0,178 & 1,546 & 0,125 \\
\hline X1 ${ }^{\star}$ 3 & 0,036 & 0,050 & 0,960 \\
\hline X2*X3 & $-0,985$ & $-1,292$ & 0,200 \\
\hline
\end{tabular}

\section{Pengujian Hipotesis 1}

Hipotesis pertama yang diajukan dalam penelitian ini adalah: "Partisipasi Penyusunan Anggaran berpengaruh terhadap Senjangan Anggaran". Berdasarkan tabel di atas diketahui bahwa nilai t hitung sebesar 5,816 dengan signifikansi 0,000 lebih kecil dari nilai $p$ value 0,05 sehingga $\mathrm{H}_{0}$ ditolak artinya koefisien jalur adalah signifikan. Dengan demikian, dapat disimpulkan bahwa Partisipasi Penyusunan Anggaran berpengaruh terhadap Senjangan Anggaran.

\section{Pengujian Hipotesis 2}

Hipotesis Kedua yang diajukan dalam penelitian ini adalah: "Ketepatan Anggaran berpengaruh terhadap Senjangan Anggaran". Berdasarkan tabel di atas diketahui bahwa nilai t hitung sebesar 1,546 dengan nilai signifikansi sebesar 0,125 lebih besar dari nilai $p$ value 0,05 sehingga $\mathrm{H}_{0}$ diterima, artinya koefisien jalur tidak signifikan. Dengan demikian, dapat disimpulkan bahwa Ketepatan Anggaran Tidak berpengaruh terhadap Senjangan Anggaran. 


\section{Pengujian Hipotesis 3}

Hipotesis ketiga yang diajukan dalam penelitian ini adalah: "Komitmen Organisasi memoderasi Pengaruh Partisipasi Penyusunan Anggaran terhadap Senjangan Anggaran". Berdasarkan tabel di atas diketahui bahwa nilai t hitung sebesar 0,050 dengan tingkat signifikansi sebesar 0,960 lebih besar dari nilai $p$ value 0,05 sehingga $H_{0}$ diterima artinya koefisien jalur tidak signifikan. Dengan demikian, dapat disimpulkan bahwa Komitmen Organisasi tidak memoderasi Pengaruh Partisipasi Anggaran terhadap Senjangan Anggaran.

\section{Pengujian Hipotesis 4}

Hipotesis keempat yang diajukan dalam penelitian ini adalah: "Komitmen Organisasi memoderasi Pengaruh Ketepatan Anggaran terhadap Senjangan anggaran". Berdasarkan tabel diatas diketahui bahwa nilai t hitung sebesar -1,292 dengan signifikansi 0,200 lebih besar dari nilai $p$ value 0,05 sehingga $H_{0}$ diterima artinya koefisien jalur tidak signifikan. Dengan demikian, dapat disimpulkan bahwa Komitmen Organisasi tidak memoderasi Pengaruh Ketepatan Anggaran terhadap Senjangan anggaran.

Jawaban terhadap masalah penelitian tersebut dapat diringkas pada tabel dibawah ini:

Tabel 6 Hasil Analisis MRA

\begin{tabular}{|l|c|c|c|}
\hline \multicolumn{1}{|c|}{ Korelasi } & Koefisien MRA & T Statistik & Keterangan \\
\hline $\mathrm{X}_{1} \rightarrow \mathrm{Y}$ & 0,575 & 5,816 & Signifikan \\
\hline $\mathrm{X}_{2} \rightarrow \mathrm{Y}$ & 0,262 & 1,546 & Tidak signifikan \\
\hline $\mathrm{X}_{1}{ }^{*} \mathrm{X}_{3} \rightarrow \mathrm{Y}$ & 0,001 & 0,050 & Tidak signifikan \\
\hline $\mathrm{X}_{2}{ }^{*} \mathrm{X}_{3} \rightarrow \mathrm{Y}$ & $-0,025$ & $-1,292$ & Tidak signifikan \\
\hline
\end{tabular}

Untuk menguji keberadaan $\mathrm{Z}$ apakah benar sebagai Pure Moderator, Quasi Moderator, atau bukan variabel moderating sama sekali, dapat diamati dengan kriteria sebagai berikut:

a. Jika Variabel Moderator (Z) signifikan dengan variabel predictor/independen $(\mathrm{X})$ atau variable criterion/dependen $(\mathrm{Y})$, namun 
interaksi variabel moderator dan independen tidak signifikan dengan variabel criterion/dependen $(\mathrm{Y})$ maka variabel $\mathrm{Z}$ tersebut bukanlah variabel moderator melainkan merupakan variabel intervening atau variabel independen.

b. Jika variabel moderator ( $Z$ ) tidak signifikan dengan variabel independen/Predictor $(\mathrm{X})$ atau dengan variabel dependen/criterion $(\mathrm{Y})$, sedangkan interaksi variabel moderator $(Z)$ dengan variabel predictor/independen $(X)$ tidak signifikan dengan variabel dependen (Y) maka variabel $\mathrm{Z}$ merupakan variabel homologizer moderator atau variabel potensi.

c. Jika variabel moderator (Z) signifikan dengan variabel independen/predictor $(\mathrm{X})$ atau dengan variabel dependen/criterion $(\mathrm{Y})$. sedangkan interaksi variabel moderator (Z) dengan variabel predictor/independen $(\mathrm{X})$ signifikan dengan variabel dependen $(\mathrm{Y})$ maka variabel $Z$ merupakan quasi moderator.

d. Jika interaksi variabel moderator $(Z)$ dengan variabel independen $(X)$ signifikan dengan variabel dependen $(Y)$ sedangkan variabel moderator $(Z)$ tidak signifikan dengan variabel predictor/criterion maka variabel $\mathbf{Z}$ tersebut merupakan variabel pure moderator (moderator murni).

Berdasarkan hasil estimasi yang digambarkan pada model dengan pendekatan Moderasi di atas, maka dapat dibuat hasil persamaan moderasi sebagai berikut :

1. Model Persamaan pengujian Hipotesis 1 dan 2:

$\mathrm{Y}=0,575 \mathrm{X}_{1}+0,262 \mathrm{X}_{2}+\mathrm{e}$

2. Model Persamaan pengujian Hipotesis 3 dan 4 :

$Y=0,624 Z+0,001 X_{1}{ }^{*} X_{3}+-0,025 X_{2}{ }^{*} X_{3}+e$ 
Maka berdasarkan hasil pengujian regresi melalui MRA bahwa komitmen merupakan didapatkan output sebagai berikut:

\section{Coefficients $^{a}$}

\begin{tabular}{|c|c|c|c|c|c|}
\hline \multirow[t]{2}{*}{ Model } & \multicolumn{2}{|c|}{$\begin{array}{c}\text { Unstandardizeo } \\
\text { Coefficients }\end{array}$} & \multirow{2}{*}{\begin{tabular}{|c|}
$\begin{array}{c}\text { Standardized } \\
\text { Coefficients }\end{array}$ \\
Beta \\
\end{tabular}} & \multirow[t]{2}{*}{$\mathrm{t}$} & \multirow[t]{2}{*}{ Sig. } \\
\hline & $B$ & $\begin{array}{l}\text { Std. } \\
\text { Error }\end{array}$ & & & \\
\hline (Constant) & $-4,649$ & 4,332 & & 1.073 & ,2ع \\
\hline $\begin{array}{l}\text { Partisipasi Penyusunan } \\
\text { Anggaran }\end{array}$ & ,287 & ,353 & ,333 & ,812 & ,419 \\
\hline 1 Ketepatan Anggaran & ,893 & 624 & ,605 & 1,432 & 156 \\
\hline Komitmen Organisasi & ,624 & , 186 & ,918 & 3,359 & 001 \\
\hline X1_X3 & ,001 & ,011 &, 036 &, 050 & ,960 \\
\hline $\mathrm{X} 2 \_\mathrm{X} 3$ &,- 025 & ,019 & -985 & 1,292 & ,200 \\
\hline
\end{tabular}

a. Dependent Variable: Senjangan Anggaran (Y)

Berdasarkan hasil output di atas dapat disimpulkan bahwa beta yang dihasilkan dari variabel $Z$ (komitmen organisasi) bernilai positif dan signifikan terhadap senjangan anggaran (beta $=0,624$; sig. $=0,001$ ). Beta yang dihasilkan dari pengaruh Interaksi X1_X3 adalah positif dan X2_X3 negatif terhadap Y. Hasil positif menunjukkan bahwa moderasi $Z$ memperkuat pengaruh dari $X$ terhadap $Y$, sedangkan hasilnya yang negatif, berarti bahwa moderasi dari $\mathrm{Z}$ memperlemah pengaruh dari $\mathrm{X}$ terhadap $\mathrm{Y}$. Meski pun memperkuat dan memperlemah, tetapi pengaruhnya tersebut tidak signifikan.

Dengan demikian dapat diketahui bahwa variable moderator Z merupakan variabel homologizer moderator atau variabel potensi karena pengaruhnya tidak signifikan terhadap variable $\mathrm{X}$ independen/predictor dan variable dependen /criterion. 


\section{PEMBAHASAN}

Pengaruh Partisipasi Penyusunan Anggaran Terhadap Senjangan Anggaran Pemerintah Kabupaten Jayapura. Hasil analisis membuktikan bahwa partisipasi Penyusunan Anggaran berpengaruh terhadap Senjangan Anggaran Pemerintah daerah. Hal ini dapat dibuktikan melalui koefisien regresi yang menunjukkan jika Partisipasi Penyusunan Anggaran meningkat, maka peningkatan tersebut diikuti oleh peningkatan Senjangan Anggaran Pemerintah daerah.

Sehingga Berdasarkan hasil pengujian pada hipotesis pertama dapat disimpulkan bahwa variabel partisipasi penyusunan anggaran mempunyai pengaruh yang signifikan terhadap Senjangan Anggaran. Hasil ini menunjukkan bahwa adanya keterlibatan atau keikutsertaan para Pimpinan dan Staf dalam proses Partispasi penyusunan anggaran.

Dengan adanya partisipasi penyusunan anggaran, para Staf di lingkungan Pemrintah diberi kesempatan untuk berperan dalam memberikan masukan-masukan dan ide ide mereka yang dituangkan dalam bentuk anggaran yang nantinya akan mereka laksanakan.

Berdasarkan temuan tersebut partisipasi penyusunan anggaran mampu memepangaruhi senjangan anggaran, maka Pemerintah Daerah yang dalam hal ini sebagai objek penelitian sedapat mungkin terus melibatkan pihak-pihak yang berkompeten dalam proses penyusunan anggaran.

Anggaran yang dibuat dengan bersama-sama dengan tujuan dan visi organisasi maka akan dilaksanakan dengan rasa penuh tanggungjawab sehingga terciptanya kinerja yang baik. Hasil penelitian ini juga sejalan dengan pendapat Dunk et. al. yang menyatakan bahwa partisipasi juga menghasilkan peluang yang lebih besar dari bawahan untuk menciptakan senjangan anggaran, hal tersebut mengacu pada pendapat bahwa partisipasi anggaran akan meningkatkan senjangan anggaran (Dunk, 1993; Lukka, 1988, Young, 1985 dalam Ikhsan dan La Ane, 2007:4). 
Diperkuat oleh pendapat Antie dan Eppen (1985) dalam Ikhsan dan Ane (2007:4) bahwa "partisipasi akan menciptakan senjangan anggaran". Argumen yang diajukan adalah bahwa semakin tinggi partisipasi yang diberikan kepada bawahan, bawahan cenderung berusaha agar anggaran yang mereka susun mudah dicapai, salah satu cara yang ditempuh adalah dengan melonggarkan anggaran atau menciptakan senjangan.

\section{Pengaruh Ketepatan Anggaran Terhadap Senjangan Anggaran} Pemerintah kabupaten Jayapura. Hasil analisis membuktikan bahwa Ketepatan Anggaran tidak berpengaruh terhadap Senjangan Anggaran Pemerintah Daerah. Akan tetapi koefisien regresi yang di dapat bernilai positif antara ketepatan anggaran terhadap senjangan anggaran pemerintah daerah, hal ini berarti jika ketepatan anggaran meningkat maka Senjangan Anggaran Pemerintah Daerah juga akan meningkat, dikarenakan pengaruh tersebut tidak signifikan maka besar pengaruh positif tersebut tidak berarti secara statistik.

Hasil penelitian ini tidak sejalan dengan penelitian Pratiwy (2013) yang menyatakan ketepatan sasaran anggaran pada pemerintah daerah akan memberikan implikasi terhadap kinerja aparatur daerah yang lebih baik, maka hasil akhir dari kinerja sendiri merupakan hasil akhir (output) organisasi yang sesuai dengan tujuan organisasi (Pratiwy, 2013). Selain itu pendapat dari penelitian oleh Astari (2015) juga bertolak belakang dengan temuan dari penelitian ini di mana Astari (2015) menemukan bahwa ketepatan sasaran anggaran berpengaruh positif terhadap akuntabilitas kinerja SKPD.

Tidak berpengaruhnya ketepatan anggaran terhadap senjangan anggaran pemerintah kabupaten Jayapura membuktikan bahwa ketepatan anggaran belum dinilai cukup untuk memberikan kontribusi dalam meningkatkan senjangan anggaran pemerintah kabupaten Jayapura, sehingga secara pengujian statistik uji t belum mendapatkan hasil pengujian yang kurang dari tingkat kesalahan alpha 0,05. 


\section{Pengaruh Partisipasi Penyusunan Anggaran Terhadap} Senjangan Anggaran Pemerintah Daerah Kabupaten Jayapura Yang Dimoderasi Oleh Komitmen Organisasi. Hasil analisis membuktikan bahwa Partisipasi Penyusunan Anggaran dengan variable Komitmen Organisasi sebagai variable pemoderasi tidak berpengaruh terhadap Senjangan Anggaran Pemerintah Daerah. Untuk mengetahui adanya pengaruh variabel komitmen organisasi dalam memoderasi hubungan partisipasi penyusunan anggaran terhadap Senjangan Anggara digunakan model nilai selisih mutlak.

Berdasarkan hasil pengujian terlihat bahwa variabel moderasi yang merupakan interaksi antara partisipasi penyusunan anggaran dengan komitmen organisasi ternyata tidak signifikan yaitu dengan signifikansinya 0,960 yang lebih besar daripada $\alpha=0,05$ dan thitung sebesar 0,050 . Hal ini berarti bahwa komitmen organisasi tidak mampu memperkuat hubungan antara partisipasi penyusunan anggaran terhadap senjangan Anggaran.

Hasil penelitian ini tidak dapat mendukung pernyataan (Porter, L. W., Steers, R. M., \& Boulian, P. V. 1974) yang menyatakan tingkat komitmen organisasi tinggi akan memiliki pandangan positif dan lebih berusaha berbuat yang terbaik demi kepentingan organissi (Porter et al, 1974). Dengan adanya komitmen yang tinggi kemungkinan terjadinya senjangan anggaran dapat dihindari.

Selain itu hasil penelitian ini juga bertolak belakang dari hasil penelitian Latuheru (2005) menyatakan bahwa semakin tinggi komitmen organisasi akan menyebabkan semakin menurunnya kecenderungan individu yang berpatisipasi dalam penyusunan anggaran untuk melakukan senjangan anggaran, atau dengan kata lain pengaruh interaksi antara komitmen organisasi dengan partisipasi anggaran dapat menurunkan kecenderungan senjangan anggaran.

Pengaruh Ketepatan Anggaran Terhadap Senjangan Anggaran Pemerintah Daerah Kabupaten Jayapura Yang Dimoderasi Oleh Komitmen Organisasi. Ketepatan anggaran dalam sistem pemerintahan 
daerah merupakan hal yang sangat diperlukan untuk mengetahui kinerja yang terjadi di lapangan apakah tepat pada sasaran pembangunan dan perkembangan masyarakat. Aparatur pemerintah daerah memiliki kejelasan untuk mengelola keuangan dengan tepat sehingga penyusunan anggaran pada periode selanjutnya dapat tercapai dengan baik pada instansi pemerintah.

Berdasarkan hasil pengujian pada hipotesis keempat ketepatan anggaran terhadap senjangan anggaran dengan komitmen organisasi sebagai pemoderasi menunjukkan bahwa komitmen organisasi tidak memoderasi pengaruh antara ketepatan anggaran senjangan anggaran, artinya komitmen organisasi tidak memperkuat hubungan ini. Berdasarkan hasil pengujian hipotesis 3 dan 4 diketahui dari hasil statistik deskriptif jawaban responden komitmen organisasi di lingkungan pemerintah dapat dikatakan tergolong rendah.

Hal ini disebabkan karena pada fakta di lapangan bahwa komitmen organisasi hanya berada di level pimpinan organisasi perangkat daerah dalam dan sedangkan di level bawah belum memiliki komitmen organisasi yang cukup baik sehingga tidak bersinggungan langsung terhadap senjangan anggaran Pemerintah Daerah.

\section{KESIMPULAN}

Partisipasi Penyusunan Anggaran Berpengaruh positif dan signifikan Terhadap Senjangan Anggaran. Hal ini mempunyai makna bahwa semakin tinggi partisipasi penyusunan anggaran maka akan membuat senjangan anggaran pemerintah daerah juga semakin tinggi.

Ketetapan Anggaran tidak Berpengaruh positif dan signifikan Terhadap Senjangan Anggaran. Hal ini berarti ketetapan anggaran tidak memiliki efek terhadap perubahan pada senjangan anggaran pemerintah daerah. 
Komitmen Organisasi tidak memoderasi Partisipasi Penyusunan Anggaran Terhadap Senjangan Anggaran. Hal ini berarti keberadaan komitmen organisasi tidak dapat memperlemah ataupun memperkuat pengaruh dari partisipasi penyusunan anggaran dengan senjangan anggaran pemerintah daerah.

Komitmen Organisasi tidak memoderasi Ketetapan Anggaran Terhadap Senjangan Anggaran. Hal ini berarti keberadaan komitmen organisasi tidak dapat memperlemah ataupun memperkuat pengaruh dari ketetapan anggaran dengan senjangan anggaran pemerintah daerah.

\section{DAFTAR PUSTAKA}

Abdullah, S. (2008). Penganggaran Partisipatif Di Pemerintahan Dan Bisnis: Perbedaan Dan Isu-Isu Penelitian. Retrieved July 20, 2009, from http://syukriy.wordpress.com/2008/12/25/penganggaran-partisipatif-dipemerintahan-dan-bisnis-perbedaan-dan-isu-isu-penelitian/

Amelia, F., Yusralaini, \& Azhar, A. (2014). Pengaruh Partisipasi Anggaran Terhadap Senjangan Anggaran Dengan Ketidakpastian Lingkungan Dan Komitmen Organisasi Sebagai Variabel Moderating Pada Perbankan Swasta Di Pekanbaru. JOM FEKON, 1(2), 1-16.

Anjarwati, M. (Universitas N. S. (2012). Pengaruh Kejelasan Sasaran Anggaran, Pengendalian Akuntansi dan Sistem Pelaporan terhadap Akuntabilitas Kinerja Instansi Pemerintah. Accounting Analysis Journal AAJ 1 (2), 1-7. https://doi.org/ISSN 2252-6765

Asriningati. (2006). Pengaruh Komitmen Organisasi Dan Ketidakpastian Lingkungan Terhadap Hubungan Antara Partisipasi Anggaran Dengan Senjangan Anggaran (Studi Kasus Pada Perguruan Tinggi Swasta Di DI Yogyakarta). Artikel IImiah. Universitas Islam Indonesia, 1-32.

Dewi, M. A. P., \& Supadmi, N. L. (2015). Pengaruh Ketepatan Sasaran Anggaran dan Pengendalian Mananjerial Sektor Publik Pada Akuntabilitas Kinerja SKPD. E-Jurnal Akuntansi Universitas Udayana 12.1, 50-63.

Dunk, A. S. (1993). The Effect of Budget Emphasis and Information Asymmetry on the Relation Between Budgetary Participation and slack. The Accounting Review, (68), 400-410.

Fatmawati, I., \& Widyaningsih, A. (2014). Pengaruh Partisipasi Anggaran Terhadap Senjangan Anggaran: Komitmen Organisasi Dan 
Ketidakpastian Lingkungan Sebagai Variabel Moderating (Penelitian pada SKPD Pemerintahan Kabupaten Serang). Jurnal Riset Akuntansi Dan Keuangan, 2(2), 338-351.

Ghozali, I. (2005). Analisis Multivariate SPSS. Semarang: Universitas Diponegoro.

Hasanah, C. U., \& Suartana, I. W. (2014). Pengaruh Interaksi Motivasi Dan Budaya Organisasi Pada Hubungan Antara Partisipasi Penyusunan Anggaran dengan Senjangan Anggaran. E-Jurnal Akuntansi Universitas Udayana 6.1, 46-62.

Herawaty, N. (2011). Pengaruh Kejelasan Sasaran Anggaran, Pengendalian Akuntansi, Dan Sistem Pelaporan Terhadap Akuntabilitas Kinerja Instansi Pemerintah Daerah Kota Jambi. Jurnal Penelitian Universitas Jambi Seri Humaniora, 13(2), 31-36.

Ikhsan, A., \& Ane, L. (2007). Pengaruh Partisipasi Anggaran Terhadap Senjangan Anggaran Dengan Menggunakan Lima Variabel Pemoderasi. Simposium Nasional Akuntan X Unhas Makasar, 53(9), 1689-1699. https://doi.org/10.1017/CBO9781107415324.004

Irfan, M., Santoso, B., \& Effendi, L. (2016). Pengaruh Partisipasi Anggaran terhadap Senjangan Anggaran dengan Asimetri Informasi, Penekanan Anggaran dan Komitmen Organisasional sebagai Variabel Pemoderasi. Jurnal Akuntansi Dan Investasi, 17(2), 158-175. https://doi.org/10.18196/jai.2016.0052.158-175

Latuheru, B. P. (2005). Pengaruh Partisipasi AnggaranTerhadap Senjangan Anggaran Dengan Komitmen Organisasi Sebagai Variabel Moderating (Studi Empiris Pada Kawasan Industri Maluku). Jurnal Akuntansi \& Keuangan2, 7(2), 117-130.

Mark Young, S. (1985). Participative Budgeting: The Effects of Risk Aversion and Asymmetric Information on Budgetary Slack. Journal of Accounting Research, 23(2), 829-842. https://doi.org/10.2307/2490840

Mercury, G. A., \& Putri, I. G. A. M. A. D. (2015). Pengaruh Partisipasi Penganggaran Dan Informasi Asimetri Pada Senjangan Anggaran Dengan Budaya Organisasi Sebagai Variabel Moderasi. E-Jurnal Akuntansi Universitas Udayana, 13(3), 1070-1099.

Nouri, H., \& Parker, R. J. (1996). The Effect of Organizational Commitment on the Relation Between Budgetary Participation and Budgetary Slack. Behavior Research in Accounting, (8), 74-89.

Onsi, M. (1973). Factor Analysis of Behavioral Variables Affecting Budgetary Slack. Accounting Review, 48(3), 535-548. https://doi.org/10.2307/245151 
Paramitha, I. A. M. D., \& Gayatri. (2016). Pengaruh Ketepatan Sasaran Anggaran, Sistem Pengendalian Manajerial Sektor Publik Dan Sistem Pelaporan Pada Akuntabilitas Kinerja. E-Jurnal Akuntansi Universitas Udayana, 16(3), 2457-2479.

Pranata, N. G. P. H., \& Putri, I. G. A. M. A. D. (2017). Internal Locus of Control Sebagai Pemoderasi Pengaruh Partisipasi Penganggaran Terhadap Senjangan Anggaran Pada Bank Perkreditan Rakyat. EJurnal Akuntansi Universitas Udayana, 19(2), 855-884.

Pratama, R. (2013). Pengaruh Partisipasi Anggaran Terhadap Senjangan Anggaran Dengan Komitmen Organisasi Dan Motivasi Sebagai Pemoderasi ( Studi Empiris pada Satuan Kerja Perangkat Daerah di Kota Padang ). Artikel IImiah. Universitas Negeri Padang., 1-20.

Putri, S. T. (2017). Pengaruh Partisipasi Anggaran Terhadap Budgetary Slack Dengan Asimetri Informasi, Ketidakpastian Lingkungan,Komitmen Organisasi, Dan Reward Sebagai Variabel Moderating Pada Satuan Kerja Perangkat Daerah (SKPD) Di Provinsi Riau. JOM Fekon, 4(1), 395-410.

Schiff, M., \& Lewin, A. Y. (1970). The impact of people on budgets. The Accounting Review, 45(2), 259-268. https://doi.org/10.2307/244377

Sugiono. (2004). Konsep, Identifikasi, Alat Analisis dan Masalah Penggunaan Variabel Moderator. Jurnal Studi Manajemen Dan Organisasi, 1, 61-70.

Sugiwardani, R. (2012). Analisis Pengaruh Partisipasi Anggaran, Informasi Asimetris, Budaya dan Komitmen Organisasi Terhadap Budgetary Slack. Artikel IImiah. STIE Perbanas Surabaya, 1-23.

Sujana, I. K. (2010). Pengaruh partisipasi penganggaran, penekanan anggaran, komitmen organisasi, asimetri informasi, dan ketidakpastian lingkungan terhadap budgetary slack pada hotel-hotel berbintang di Kota Denpasar. Jurnal Ilmiah Akuntansi Dan Bisnis, 1-26.

Venusita, L. (2007). Partisipasi Anggaran dan Keterlibatan Kerja terhadap Senjangan Anggaran dengan Komitmen Organisasi sebagai Variabel Moderasi (Studi pada Perusahaan Industri Food and Beverage di Kawasan Industri SIER). Jurnal Kewirausahaan, 2(1), 1-13.

Wiener, Y. (1982). Commitment in Organizations: A Normative View. Academy of Management Review, (7), 418-428. 